\title{
A Comparison of Jurkat Cell-Reactive Anti-T Lymphocyte Globulin and Fetal Anti-Thymocyte Globulin Preparations in the Treatment of Aplastic Anemia
}

\author{
Songul Serefhanoglu ${ }^{\mathrm{a}}$ Yahya Buyukasik ${ }^{\mathrm{a}}$ Tugrul Purnak ${ }^{\mathrm{b}}$ Hakan Goker $^{\mathrm{a}}$ \\ Nılgun Sayinalp ${ }^{a} \quad$ Ibrahim C. Haznedaroglua Osman I. Ozcebe ${ }^{a}$ \\ ${ }^{a}$ Division of Hematology and ${ }^{b}$ Department of Internal Medicine, Hacettepe University Hospital, Ankara, Turkey
}

\section{Key Words}

Aplastic anemia - Lymphoglobulin ${ }^{\circledR}$. Thymoglobulin ${ }^{\circledR}$. ATG-Fresenius ${ }^{\circledR}$

\section{Abstract}

Objective: The aim of this study was to investigate the success rate and effects on survival of different anti-thymocyte globulin (ATG) preparations in patients diagnosed with aplastic anemia. Subjects and Methods: Of the total 24 patients included in the study, 12 were male and 12 female with a median age of 44 years (range 16-72). Nine patients received Lymphoglobulin ${ }^{\circledR}, 7$ Thymoglobulin ${ }^{\circledR}$ and ATG-Fresenius $^{\circledR}$ (ATG-F). There was no significant difference between the three treatment groups in terms of severity of aplastic anemia. Results: The estimated 6-month survival rates for ATG-F, Lymphoglobulin and Thymoglobulin groups were $42.9,77.8$ and $71.4 \%$, respectively. The difference in overall survival rates between groups was not significant, most likely due to the low number of patients. The most striking result was that none of the patients in the ATG-F preparation group showed any response to treatment. The ATG-F group was found to have a significantly inferior response rate $(p=0.07)$.
Conclusion: Our data showed that none of the patients responded to ATG-F treatment. Hence, despite the small number of the patients, we recommend that ATG-F should not be used for treatment of severe aplastic anemia.

Copyright $\odot 2011$ S. Karger AG, Basel

\section{Introduction}

Severe aplastic anemia is a life-threatening disease characterized by peripheral blood pancytopenia and hypocellular bone marrow. The prevalence of aplastic anemia is estimated at 1-2 per 1 million people with a higher incidence in some regions of Asia. Aplastic anemia is a disease of young adults (15-30 years), but a second peak in incidence has been reported in the sixth decade of life [1]. The mechanism of bone marrow failure is immunemediated such that the suppression of hematopoiesis in aplastic anemia is probably secondary to activated cytotoxic lymphocytes [2]. Immunosuppressive therapy is a major treatment modality for severe aplastic anemia and anti-thymocyte globin (ATG)/anti-lymphocyte globin (ALG) is usually used. Cyclosporine is another immuno-

\section{KARGER}

Fax +4161306 1234

E-Mail karger@karger.ch

www.karger.com
(C) 2011 S. Karger AG, Basel

$1011-7571 / 11 / 0204-0341 \$ 38.00 / 0$

Accessible online at:

www.karger.com/mpp
Dr. Songul Serefhanoglu

Hacettepe University Hospital

Department of Internal Medicine, Division of Hematology

TR-06030 Ankara (Turkey)

Tel. +90 312305 1453, Fax +90 312305 1536, E-Mail dr.songul1978@yahoo.com 
suppressive drug used for aplastic anemia therapy. The addition of cyclosporine led to higher hematologic response rates (60-70\%) and more complete responses than observed with ATG alone [3]. Bone marrow transplantation remains the treatment of choice in patients if an appropriate family donor is available. Children have a low rate of graft-versus-host disease, which is cured by stem cell transplantation. Adults also successfully receive transplants, although the risk and severity of graft-versus-host disease and other transplant-related complications increase with age. ATG/cyclosporine combination therapy is considered the standard therapy for patients with severe or very severe aplastic anemia and transfusion-dependent nonsevere aplastic anemia, without suitable donors for stem cell transplantation [4].

Three different immunosuppressive therapy regimens, ALG, ATG and rabbit ATG (ATG-Fresenius ${ }^{\circledR}$, ATG-F) are used as treatment of aplastic anemia. Thoracic duct lymphocytes are the antigens for ALG; thymocytes are the immunogens used for the production of ATG. Both appear to have much higher efficacy for treatment of aplastic anemia [5-7]. ATG-F is isolated from the serum of rabbits immunized with human $\mathrm{T}$ lymphoblasts from the human Jurkat cell line instead of children's thoracic duct lymphocytes or thymocytes. The thoracic duct lymphocyte ATG, a product called Lymphoser, is no longer produced. Both Thymoglobulin ${ }^{\circledR}$ and Lymphoglobulin ${ }^{\circledR}$, produced with thymocytes of newborns, are used for stimulation, whereas ATG-F is produced with the cultured Jurkat cell line. Furthermore, there are species differences. Lymphoglobulin is a horse product whereas Thymoglobulin and ATG$\mathrm{F}$ are rabbit products. There are, therefore, two main variables to be considered: animal species and stimulating cells. The therapeutic mechanisms of ATG/ALG are immunosuppressive, immunostimulatory and direct effect on hematopoietic stem cells, but the mechanism of ATG$\mathrm{F}$ is restricted to an immunosuppressive effect [8]. Hence, this study was designed to investigate the effects on survival and success rate of different ATG preparations in patients diagnosed with aplastic anemia.

\section{Subjects and Methods}

The records of patients diagnosed with aplastic anemia at Hacettepe University Faculty of Medicine, Department of Internal Medicine, Hematology Clinic between January 1993 and January 2005 and who had received ATG treatment were evaluated. All patients $(n=24)$ were evaluated using established criteria of aplastic anemia prior to initiation of therapy. These criteria included bone marrow cellularity of $<30 \%$, peripheral blood pan-
Table 1. Patient characteristics

\begin{tabular}{|c|c|c|c|c|}
\hline & $\begin{array}{l}\text { ATG-F } \\
(\mathrm{n}=8)\end{array}$ & $\begin{array}{l}\text { LNF } \\
(n=9)\end{array}$ & $\begin{array}{l}\text { TMG } \\
(\mathrm{n}=7)\end{array}$ & $\begin{array}{l}\mathrm{p} \\
\text { value }\end{array}$ \\
\hline \multicolumn{5}{|l|}{ Age, years } \\
\hline Median & 27.5 & 35 & 53 & \multirow[t]{2}{*}{ NS } \\
\hline Range & $16-62$ & $17-65$ & $25-72$ & \\
\hline Gender, F/M & $5 / 3$ & $5 / 4$ & $2 / 5$ & NS \\
\hline \multicolumn{5}{|c|}{ Aplastic anemia severity } \\
\hline Severe & 8 & 7 & 7 & \multirow[t]{2}{*}{ NS } \\
\hline Nonsevere & 0 & 2 & 0 & \\
\hline \multicolumn{5}{|l|}{ Response } \\
\hline Complete & 0 & 4 & 2 & \multirow[t]{3}{*}{0.11} \\
\hline Partial & 0 & 2 & 1 & \\
\hline None & 4 & 1 & 3 & \\
\hline \multicolumn{5}{|l|}{ Early mortality } \\
\hline$<3$ months & 4 & 2 & 1 & NS \\
\hline \multicolumn{5}{|c|}{ Hemoglobin level, g/dl } \\
\hline Median & 8.9 & 7 & 9.7 & \multirow[t]{2}{*}{ NS } \\
\hline Range & $4.5-11.9$ & $2.4-11.5$ & $5.4-11.2$ & \\
\hline \multicolumn{5}{|c|}{ White blood cell count per $\mathrm{mm}^{3}$} \\
\hline Median & 2,500 & 2,100 & 3,100 & \multirow[t]{2}{*}{ NS } \\
\hline Range & $400-3,800$ & $1,000-3,600$ & $800-3,500$ & \\
\hline \multicolumn{5}{|c|}{ Platelet count per $\mathrm{mm}^{3}$} \\
\hline Median & 19,000 & 23,000 & 20,000 & \multirow[t]{2}{*}{ NS } \\
\hline Range & $\begin{array}{l}5,000- \\
134,000\end{array}$ & $\begin{array}{l}3,000- \\
100,000\end{array}$ & $\begin{array}{l}6,000- \\
110,000\end{array}$ & \\
\hline
\end{tabular}

LNF = Lymphoglobulin; TMG = Thymoglobulin; nonsevere aplastic anemia $=$ polymorphonuclear cells $>0.5 \mathrm{~g} / \mathrm{l}$; severe aplastic anemia $=$ polymorphonuclear cells $<0.2 \mathrm{~g} / \mathrm{l} ; \mathrm{F}=$ female; $\mathrm{M}=$ male; NS = nonsignificant.

cytopenia and absolute reticulocyte cellularity of $<30 \%$ defined as hypocellularity, decreases in each of the three series, increases in the size and number of individual fat and stromal cells in the absence of atypical hematopoietic cell morphology, malignant infiltration, myelofibrosis and megaloblastoid features. In patients with severe aplastic anemia peripheral blood pancytopenia was present if two of three peripheral blood criteria were met: absolute neutrophil count $<500$ cells $/ \mathrm{mm}^{3}$, platelet count $<20,000$ cells/ $\mathrm{mm}^{3}$, reticulocyte count $<40,000$ cells $/ \mathrm{mm}^{3}$ in the absence of other hematological disease. Moderate aplastic anemia was defined as pancytopenia not fulfilling the criteria for severe disease, absolute reticulocyte count being defined as $<1 \%$ (corrected for hematocrit). There was no difference between the patients of the three groups in terms of severity of aplastic anemia.

Exclusion criteria were a follow-up duration of less than 3 months and having received another treatment within 3 months of ATG treatment. According to these criteria, 9 patients were excluded from the study. Nine patients received Lymphoglobulin, 7 Thymoglobulin, and 8 patients ATG-F. Patient characteristics are given in table 1 . A total of 24 patients with a median age of 44 years (16-72), 50\% of whom were male and $50 \%$ female, received the treatment. 
Table 2. Response rates

\begin{tabular}{lllll}
\hline & $\begin{array}{l}\text { ATG-F } \\
(\mathrm{n}=8)\end{array}$ & $\begin{array}{l}\text { LNF } \\
(\mathrm{n}=9)\end{array}$ & $\begin{array}{l}\text { TMG } \\
(\mathrm{n}=7)\end{array}$ & $\begin{array}{l}\mathrm{p} \\
\text { value }\end{array}$ \\
\hline $\begin{array}{l}\text { Complete response } \\
\text { Partial response }\end{array}$ & 0 & 4 & 2 & 0.11 \\
$\begin{array}{l}\text { No response } \\
\begin{array}{l}\text { Follow-up time, days } \\
\quad \text { Total }\end{array}\end{array}$ & 0 & 2 & 1 & \\
$\quad 3$ & 1 & 3 & \\
$\quad \begin{array}{l}\text { Median } \\
\quad \text { Range }\end{array}$ & $3-1,668$ & $10-2,488$ & $66-2,992$ & \\
6-month survival rate, \% & $5-1,668$ & $10-2,480$ & $61-2,825$ & \\
\hline
\end{tabular}

LNF = Lymphoglobulin; TMG = Thymoglobulin.

After premedication with diphenhydramine and acetaminophen, Thymoglobulin was administered at $2.5-5 \mathrm{mg} / \mathrm{kg} /$ day intravenously (i.v.), Lymphoglobulin at $15 \mathrm{mg} / \mathrm{kg} /$ day i.v., and ATG-F at 3-5 mg/kg/day (recommended doses after solid organ transplantation). All three preparations were administered for 5 consecutive days. In the ATG-F group, 1 patient received 7.5 and another $10 \mathrm{mg} / \mathrm{kg} /$ day for 7 consecutive days. Moderate doses $(1 \mathrm{mg} / \mathrm{kg} / \mathrm{day})$ of prednisone or methylprednisolone were administered during the first 2 weeks to ameliorate the symptoms of serum sickness, and gradually reduced the following week. Cyclosporine was started on day 1 at $5 \mathrm{mg} / \mathrm{kg} /$ day by mouth in divided doses every $12 \mathrm{~h}$. Dosing was adjusted to maintain a drug level of $200-400 \mathrm{ng} / \mathrm{ml}$ and was administered for at least 180 days. Treatment efficacy was classified as complete response (CR), partial response (PR) and no response (NR), respectively.

\section{Statistical Analyses}

Statistical analyses were performed using the SPSS statistical package (version 15.0, SPSS, Chicago, Ill., USA). The differences between survival curves were tested for statistical significance using the $\chi^{2}$ test. Overall survival was determined from the time of entry into the study to total follow-up time. Patients who were lost to follow-up were eliminated at the time of the last visit. Responseto-treatment rates for all ATG preparations were evaluated using $\chi^{2}$ test, and survival rates were evaluated using Kaplan-Meier and log-rank tests. A p value $<0.05$ was considered to be significant. The difference in overall survival rates between the groups was statistically insignificant ( $\mathrm{p}=0.117$ ), but the significance lies in the fact that this is a very rare disease.

\section{Results}

Patient characteristics are given in table 1. The comparison of response rates among the three groups is given in table 2. Follow-up characteristics are given in table 3. For the ATG-F group, 4 patients had NR and 4 patients died during first 3 months of treatment. For the Lympho-
Table 3. Follow-up characteristics of all patients

\begin{tabular}{|c|c|c|c|c|c|}
\hline Group & $\begin{array}{l}\text { Follow-up } \\
\text { time after first } \\
\text { treatment, days }\end{array}$ & Result & $\begin{array}{l}\text { Additional } \\
\text { treatment-1 }\end{array}$ & $\begin{array}{l}\text { Additional } \\
\text { treatment-2 }\end{array}$ & $\begin{array}{l}\text { Final } \\
\text { outcome }\end{array}$ \\
\hline ATG-F & 5 & death & & & death \\
\hline ATG-F & 7 & death & & & death \\
\hline ATG-F & 22 & death & & & death \\
\hline ATG-F & 65 & death & & & death \\
\hline ATG-F & 126 & NR & & & $\mathrm{NR}$, alive \\
\hline ATG-F & 535 & NR & ATG-F & & death \\
\hline ATG-F & 1,085 & NR & ATG-F & & $\mathrm{NR}$, alive \\
\hline ATG-F & 1,668 & NR & ATG-F & AlloSCT & $\mathrm{CR}$, alive \\
\hline TMG & 61 & death & & & death \\
\hline TMG & 83 & $\mathrm{PR}$ & & & $\mathrm{PR}$, alive \\
\hline TMG & 99 & NR & & & death \\
\hline TMG & 427 & NR & LNF & & $\mathrm{NR}$, alive \\
\hline TMG & 731 & CR & & & $\mathrm{CR}$, alive \\
\hline TMG & 1,183 & NR & AlloSCT & & $\mathrm{CR}$, alive \\
\hline TMG & 2,825 & CR & & & $\mathrm{CR}$, alive \\
\hline LNF & 10 & death & & & death \\
\hline LNF & 40 & death & & & death \\
\hline LNF & 92 & NR & TMG & & $\mathrm{NR}$, alive \\
\hline LNF & 416 & CR & & & $\mathrm{CR}$, alive \\
\hline LNF & 497 & CR & & & $\mathrm{CR}$, alive \\
\hline LNF & 783 & PR & LNF & & $\mathrm{PR}$, alive \\
\hline LNF & 1,373 & PR & TMG & & $\mathrm{CR}$, alive \\
\hline LNF & 1,577 & CR & & & $\mathrm{CR}$, alive \\
\hline LNF & 2,480 & CR & & & $\mathrm{CR}$, alive \\
\hline
\end{tabular}

LNF = Lymphoglobulin; TMG = Thymoglobulin; AlloSCT = allogeneic stem cell transplantation; $\mathrm{CR}=$ complete response; $\mathrm{PR}=$ partial response; $\mathrm{NR}=$ no response.

globulin group 4 patients achieved CR, 2 achieved PR, 1 had NR and 2 died during the first 3 months. For the Thymoglobulin group, 2 patients achieved CR, 1 achieved PR, 3 had NR and 1 died during first 3 months. The estimated 6-month survival rates for the ATG-F, Lymphoglobulin and Thymoglobulin groups were 42.9, 77.8 and $71.4 \%$, respectively. The most striking result was that none of the patients in the ATG-F preparation group showed any response to treatment. The ATG-F group had an inferior response rate $(\mathrm{p}=0.07)$.

Of the 8 patients who received ATG-F treatment, 3 were administered a repeat ATG-F treatment. Of those 3 patients 1 died, the second had NR, and the third had CR following allogeneic stem cell transplantation. Of the 7 patients who received Thymoglobulin treatment: 1 received Lymphoglobulin in addition and had NR; another had CR following allogeneic stem cell transplantation. Of 
the 9 patients who received Lymphoglobulin treatment, 2 received Thymoglobulin in addition, 1 of whom had NR while the other had CR. One patient who received repeat Lymphoglobulin treatment had PR (table 3).

\section{Discussion}

Among the patients treated with the three preparations Lymphoglobulin, Thymoglobulin and ATG-F, none of the patients treated with ATG-F showed any response. A previous study using Lymphoglobulin alone; Lymphoglobulin and cyclosporine; Lymphoglobulin, cyclosporine, recombinant human granulocyte-macrophage colony-stimulating factor and rhu erythropoietin (rhuEPO); or rabbit ATG (ATG-F), cyclosporine, rhuGM-CSF and rhu-EPO showed that the response rate to ATG-F, cyclosporine, rhuGM-CSF and rhu-EPO (53\%) was significantly lower $(\mathrm{p}=0.039)$ than for the other treatment groups. Our finding was similar to that of Zheng et al. [9], who used ATG-F in combination with cyclosporine,
rhuGM-CSF and rhu-EPO. It should be pointed out that ATG-F is not an anti-T lymphocyte or thymocyte globulin. It is isolated from the serum of rabbits immunized with the human Jurkat cell line of T lymphoblasts instead of children's thoracic duct lymphocytes or thymocytes. Although limited, there are data indicating that these preparations have different mechanisms of action [8]. The therapeutic mechanisms of the classical agents are immunosuppressive, immunostimulatory and direct effects on hematopoietic stem cells. However, the mechanism of ATG-F is restricted to an immunosuppressive effect [8].

The limitations of our study are its retrospective design and small sample size. The low patient numbers were due to the fact that immunosuppressive treatment has only been indicated for cases not eligible for allogeneic transplant. Despite the limitations of this study, we believe that the use of ATG-F as a novel treatment for aplastic anemia should be challenged, since its efficacy is still under close scrutiny.

\section{References}

1 Kojima S: Aplastic anemia in the Orient. Int J Hematol 2002;76:173-174.

2 Young NS: Acquired aplastic anemia. Ann Intern Med 2002;136:534-546.

3 Marsh JC, Ball SE, Darbyshire P, GordonSmith EC, Keidan AJ, Martin A, McCann SR, Mercieca J, Oscier D, Roques AW, Yin JA: Guidelines for the diagnosis and management of acquired aplastic anemia. Br J Haematol 2003;123:782-801.

4 Rosenfeld S, Follmann D, Nunez O, Young NS: Antithymocyte globulin and cyclosporine for severe aplastic anemia: association between hematologic response and longterm outcome. JAMA 2003;289:1130-1135.
5 Young NS, Maciejewski JP: Aplastic anemia; in Hoffman R, Benz SJ, Shattil SJ, Furie B, Silberstein LE, McGlave P, Heslop H (eds): Hematology: Basic Principles and Practice. Philadelphia, Churchill Livingstone, 2005, pp 381-407.

6 Young NS, Barrett AJ: The treatment of severe acquired aplastic anemia. Blood 1995; 85:3367-3377.

7 Paquette RL, Tebyani N, Frane M, Ireland P, Ho WG, Champlin RE, Nimer SD: Long term outcome of aplastic anemia in adults treated with antithymocyte globulin: comparison with bone marrow transplantation. Blood 1995;85:283-290.
$>8$ Eiermann TH, Freitag S, Cortes-Dericks L, Sahm H, Zander AR: Jurcat cell-reactive anti-thymocyte globulin assessed ex vivo by flow cytometry persists three weeks in circulation. J Hematother Stem Cell Res 2001;10: 385-390.

9 Zheng Y, Liu Y, Chu Y: Immunosuppressive therapy for acquired severe aplastic anemia (SAA): a prospective comparison of four different regimens. Exp Hematol 2006;34:826831. 